\section{Dolomite and Micronutrient Fertilizer Affect Phosphorus Fate When Growing Crape Myrtle in Pine Bark}

\author{
Jacob H. Shreckhise
}

U.S. Department of Agriculture, Agricultural Research Service, Application

Technology Research Unit, 1680 Madison Avenue, Wooster, OH 44691

James S. Owen, Jr.

U.S. Department of Agriculture, Agricultural Research Service, Application

Technology Research Unit, 1680 Madison Avenue, Wooster, OH 44691

Matthew J. Eick

School of Plant and Environmental Sciences, 185 Ag Quad Lane, 237 Smyth Hall, Virginia Tech, Blacksburg, VA 24061

\author{
Alexander X. Niemiera \\ School of Plant and Environmental Sciences, 409 West Campus Drive, 401-A \\ Saunders Hall, Virginia Tech, Blacksburg, VA 24061
}

James E. Altland

U.S. Department of Agriculture, Agricultural Research Service, Application Technology Research Unit, 1680 Madison Avenue, Wooster, OH 44691

\section{Brian E. Jackson}

Department of Horticultural Science, North Carolina State University, 227 Kilgore Hall, Campus Box 7609, Raleigh, NC 27695

Additional index words. chemical speciation, controlled-release fertilizer, Lagerstroemia, mineral nutrient uptake, phosphorus fractionation, soilless substrate

Abstract. Soilless substrates are routinely amended with dolomite and sulfate-based micronutrients to improve fertility, but the effect of these amendments on phosphorous $(P)$ in substrate pore-water during containerized crop production is poorly understood. The objectives of this research were as follows: compare the effects of dolomite and sulfate-based micronutrient amendments on total $P$ (TP), total dissolved P (TDP), orthophosphate $P(O P)$, and particulate $P$ (PP; TP - TDP) concentrations in pourthrough extracts; to model saturated solid phases in substrate pore-water using Visual MINTEQ; and to assess the effects of dolomite and micronutrient amendments on growth and subsequent $P$ uptake efficiency (PUE) of Lagerstroemia L. 'Natchez' (crape myrtle) potted in pine bark. Containerized crape myrtle were grown in a greenhouse for 93 days in a $100 \%$ pine bark substrate containing a polymer-coated $19 \mathrm{~N}-2.6 \mathrm{P}-10.8 \mathrm{~K}$ controlled-release fertilizer (CRF) and one of four substrate amendment treatments: no dolomite or micronutrients (control), $2.97 \mathrm{~kg} \cdot \mathrm{m}^{-3}$ dolomite (FL); $0.89 \mathrm{~kg} \cdot \mathrm{m}^{-3}$ micronutrients (FM); or both dolomite and micronutrients (FLM). Pour-through extracts were collected approximately weekly and fractioned to measure pore-water TP, TDP, and $O P$ and to calculate PP. Particulate $P$ concentrations in pour-through extracts were generally unaffected by amendments. Relative to the control, amending pine bark with FLM reduced water-extractable $O P$, TDP, and TP concentrations by $\approx 56 \%$, had no effect on $P$ uptake efficiency, and resulted in 34\% higher total dry weight (TDW) of crape myrtle. The FM substrate had effects similar to those of FLM on plant TDW and PUE, and $F M$ reduced pore-water OP, TDP, and TP concentrations by $32 \%$ to $36 \%$ compared with the control. Crape myrtle grown in FL had $28 \%$ lower TDW but pour-through OP, TDP, and TP concentrations were similar to those of the control. Chemical conditions in FLM were favorable for precipitation of manganese hydrogen phosphate $\left(\mathrm{MnHPO}_{4}\right)$, which may have contributed to lower water-extractable $P$ concentrations in this treatment. This research suggests that amending pine bark substrate with dolomite and a sulfate-based micronutrient fertilizer should be considered a best management practice for nursery crop production.

Nutrient enrichment and subsequent eutrophication of receiving waters from agriculture have profound effects on aquatic resources. Proliferation of primary pro-

ducers, including toxic cyanobacteria species, induced by increased nutrient levels in aquatic ecosystems has resulted in loss of species biodiversity, contamination of drink- ing water, and widespread fish kills (Carpenter et al., 1998). Eutrophication occurs when critical concentrations of both $\mathrm{N}$ and $\mathrm{P}$ are present; however, $\mathrm{P}$ is generally regarded as the limiting nutrient for the accelerated growth of photosynthesizing organisms (e.g., phytoplankton, algae, cyanobacteria, plants) in fresh water ecosystems (Correll, 1998; Khan and Mohammad, 2014; Schindler et al., 2008). Boesch et al. (2001) and Michalak et al. (2015) concluded that P runoff from agricultural operations is a primary contributor to eutrophication in the United States.

Substrates used in containerized nursery crop production predominantly comprise pine bark (Pinus taeda L.) in the southeastern United States (Bilderback et al., 2013b; Lu et al., 2006). Pine bark-based substrates have little ability to sorb fertilizer $P$, thus enabling $\mathrm{P}$ to readily leach from containers during irrigation (Marconi and Nelson, 1984; Paradelo et al., 2017; Yeager and Wright, 1982). The best management practice (Bilderback et al., 2013a) of using polymer- or resin-coated controlled-release fertilizers (CRFs) is, in part, used to reduce P leaching and runoff relative to the use of soluble fertilizers (Broschat, 1995; Diara et al., 2014). According to survey studies, CRFs have been widely adopted by the nursery industry in the United States (Dennis et al., 2010; Fain et al., 2000; Mack et al., 2017). However, P uptake efficiency (PUE; percent of applied $\mathrm{P}$ taken by plant roots) is generally poor for container-grown nursery crops fertilized with CRFs and ranges from $7 \%$ to $62 \%$, depending on the fertilization and irrigation management strategies used (McGinnis et al., 2009; Owen et al., 2008; Tyler et al., 1996b; Warren et al., 1995, 2001).

The PUE in containerized crop production is affected by cultural practices and substrate amendments. Studies by Lea-Cox and Ristvey (2003) and Ristvey et al. (2004, 2007 ) found that decreasing the P fertilization amount increased the PUE of Rhododendron L. 'Karen'. Warren et al. (1995) determined that resin-coated $\mathrm{P}$ resulted in higher PUE than sulfur-coated P or composted turkey litter when producing Rhododendron L. 'Sunglow'. McGinnis et al. (2009) observed higher PUE of Hibiscus moscheutos L. 'Luna Blush' when supplying $\mathrm{P}$ via vermicompost compared with CRF. When growing containerized Cotoneaster dammeri C.K.Schneid. 'Skogholm', Owen et al. (2008) reported improved PUE in plants that received a $50 \%$ lower CRF-P application rate or when grown in pine bark substrate amended with $11 \%$ (by volume) calcined palygorksite clay. Other studies have demonstrated that various clay products reduce $\mathrm{P}$ leaching from containers when mixed into a pine bark substrate (Ogutu and Williams, 2009; Owen et al., 2007; Ruter, 2004).

Dolomite $\left[\mathrm{CaMg}\left(\mathrm{CO}_{3}\right)_{2}\right]$ and micronutrient amendments are routinely mixed into container substrates before potting. Dolomitic limestone is used to increase substrate $\mathrm{pH}$ and supply plants with calcium $(\mathrm{Ca})$ and 
magnesium (Mg). Phosphorus sorption by dolomite has been well-established in studies examining its use as a $\mathrm{P}$ adsorbent for wastewater treatment (Karaca et al., 2004, 2006; Mangwandi et al., 2014; Xu et al., 2014; Yuan et al., 2014, 2015). Additionally, the ability of dolomite to sorb $\mathrm{P}$ in peat- or pine bark-based substrates has been studied during containerized crop production research (Argo and Biernbaum, 1996a, 1996b; Havis and Baker, 1985; Haynes, 1982; Shreckhise et al., 2019).

Micronutrient fertilizers provide boron (B), chloride $(\mathrm{Cl})$, copper $(\mathrm{Cu})$, iron $(\mathrm{Fe})$, manganese $(\mathrm{Mn})$, molybdenum (Mo), nickel (Ni), and zinc $(\mathrm{Zn})$ in sulfated or chelated forms, and some micronutrient fertilizers supply plants with additional $\mathrm{Ca}$ and $\mathrm{Mg}$. Shreckhise et al. (2019) found that compared with a nonamended substrate, a sulfate-based micronutrient fertilizer reduced orthophosphate $\mathrm{P}(\mathrm{OP})$ concentrations in leachate by more than $50 \%$ in fallow columns of CRFfertilized pine bark substrate after the first five $2.6-\mathrm{cm}$ irrigation events. The authors also reported that on day 48 of daily irrigation (totaling $\approx 125 \mathrm{~cm}$ of applied tap water), OP concentrations in leachate were at least $50 \%$ lower in pine bark amended with both dolomite and micronutrients compared with nonamended pine bark. In addition to reducing $\mathrm{P}$ runoff from container nursery sites, conven-

Received for publication 15 Jan. 2020. Accepted for publication 18 Mar. 2020.

Published online 7 May 2020.

This publication is a portion of a dissertation submitted by Jacob H. Shreckhise in partial fulfillment of the degree of Doctor of Philosophy at Virginia Tech. The use of trade or brand names in this publication does not constitute a guarantee or warranty of the product by Virginia Tech and does not imply its approval to the exclusion of other products or vendors that also may be suitable. We thank Julie Brindley, Velva Groover, Anna Birnbaum, and Doug Sturtz for technical assistance, as well as Carolina Bark Products and Harrell's LLC for donating pine bark and fertilizer, respectively, for this research. Special thanks to Saunders Brothers Nursery for donating plant material and to Sarah White and her team for DOC sample analyses.

Funding was provided by the Virginia Agricultural Experiment Station and the Hatch Program of the National Institute of Food and Agriculture (SCRI 2014-51181-22372), U.S. Department of Agriculture, the Horticultural Research Institute, and the Virginia Nursery and Landscape Association.

J.H.S. is a Research Plant Physiologist; formerly $\mathrm{PhD}$ Candidate.

J.S.O. is a Research Horticulturist; formerly an Associate Professor at the School of Plant and Environmental Sciences, Virginia Tech, Hampton Roads Agricultural Research and Extension Center, Virginia Beach, VA 23455.

M.J.E. and A.X.N. are Professors.

J.E.A. is a Research Horticulturist.

B.E.J. is an Associate Professor.

J.S.O. is the corresponding author. E-mail: jim. owen@usda.gov.

This is an open access article distributed under the CC BY-NC-ND license (https://creativecommons.org/ licenses/by-nc-nd/4.0/). tional dolomite and micronutrient amendments added to soilless substrate may improve the PUE of container-grown crops because $\mathrm{P}$ is retained in the root zone. In contrast to soils, pine bark substrates have no appreciable source of labile $\mathrm{P}$ to resupply pore-water with OP during root uptake. However, the effects of dolomite and micronutrients in pine bark substrate on PUE of containerized crops have not been investigated.

Phosphorus recovery has been reported to be between $16 \%$ and $57 \%$ in containerized nursery trials attempting to recover all fertilizer P partitioned in the effluent, plant, substrate, and nondissolved fertilizer (McGinnis et al., 2009; Owen et al., 2008; Ristvey et al., 2004; Tyler et al., 1996a; Warren et al., 2001). In these studies, a definitive explanation for incomplete $P$ recovery has not been reported. We postulate that low $\mathrm{P}$ recovery was a factor of the analytical method used to measure $\mathrm{P}$. The $\mathrm{P}$ concentrations in effluent of containerized nursery crops are commonly measured colorimetrically after filtration through a $0.45-\mu \mathrm{m}$ membrane as dissolved reactive $P$, which is the $P$ fraction available for plant uptake. In all of the aforementioned $\mathrm{P}$ budget studies, effluent $\mathrm{P}$ was reported as dissolved reactive $\mathrm{P}$ or $\mathrm{PO}_{4}-\mathrm{P}$ (i.e., orthophosphate $\mathrm{P}$ ). Therefore, effluent $\mathrm{P}$ associated with metals supplied by the dissolution of dolomite and micronutrients (e.g., $\mathrm{Ca}, \mathrm{Mg}$, $\mathrm{Mn}, \mathrm{Fe}$ ), would not have been detected and may account for a portion of the nonrecovered $\mathrm{P}$. When measuring $\mathrm{P}$ fractions in leachate of daily irrigated (i.e., $\approx 2.6 \mathrm{~cm} \cdot \mathrm{d}^{-1}$ ) fallow pine bark columns, Shreckhise et al. (2019) reported that OP contributed between $12 \%$ and $50 \%$ of total P (TP) measured on days $1,5,9,15$, and 23 , regardless of dolomite and micronutrient additions. Comparing relative amounts of $\mathrm{TP}$, total dissolved $\mathrm{P}$ (TDP), and OP in pore-water of pine bark substrate containing dolomite and micronutrients would build on our understanding of the fate of $\mathrm{P}$ in containerized crop production. The objectives of this research were as follows: to 1) compare the effects of dolomite and micronutrient amendments on TP, TDP, $\mathrm{OP}$, and particulate $\mathrm{P}$ (PP; TP - TDP) concentrations in pour-through extracts; 2 ) model saturated solid phases in substrate pore-water using a geochemical speciation software (Visual MINTEQ); and 3) assess the effects of dolomite and micronutrient amendments on growth and subsequent $\mathrm{P}$ use efficiency of Lagerstroemia L. 'Natchez' (crape myrtle) potted in pine bark with incorporated CRF.

\section{Materials and Methods}

On 10 Feb. 2017, 60 dormant Lagerstroemia L. 'Natchez' (crape myrtle) liners were acquired in 15-cell trays (1-L cells) from Saunders Brothers Nursery (Piney River, VA). Crape myrtle was chosen due to its popularity in the southeastern nursery industry and relatively fast growth rate, which would ensure a quantifiable level of nutrient uptake. Of the 60 liners, the 20 most
Table 1. Pine bark elemental analysis determined by Brookside Laboratories (New Bremen, $\mathrm{OH}$ ) using a Thermal 6500 Duo inductively coupled plasma optical emission spectrometer (ICPOES) following microwave-assisted nitric acid digestion (Peters et al., 2003).

\begin{tabular}{lc}
\hline \multicolumn{2}{c}{ Pine bark elemental analysis } \\
\hline $\mathrm{N}(\%)$ & 0.31 \\
$\mathrm{P}(\%)$ & 0.01 \\
$\mathrm{~K}(\%)$ & 0.10 \\
$\mathrm{Ca}(\%)$ & 0.23 \\
$\mathrm{Mg}(\%)$ & 0.05 \\
$\mathrm{~S}(\%)$ & 0.04 \\
$\mathrm{~B}\left(\mathrm{mg} \cdot \mathrm{kg}^{-1}\right)$ & 4.3 \\
$\mathrm{Fe}\left(\mathrm{mg} \cdot \mathrm{kg}^{-1}\right)$ & 184.0 \\
$\mathrm{Mn}\left(\mathrm{mg} \cdot \mathrm{kg}^{-1}\right)$ & 79.3 \\
$\mathrm{Cu}\left(\mathrm{mg} \cdot \mathrm{kg}^{-1}\right)$ & 6.9 \\
$\mathrm{Zn}\left(\mathrm{mg} \cdot \mathrm{kg}^{-1}\right)$ & 27.5 \\
$\mathrm{C}: \mathrm{N}$ & 189 \\
\hline
\end{tabular}

uniform single-trunk plants were selected for this study and pruned to a height of $30 \mathrm{~cm}$.

Pine bark (aged at least 8 months; 15.9mm screen) was obtained from Carolina Bark Products (Seaboard, NC) on 21 Feb. 2017. Measured air space and container capacity (by volume) of the substrate were $22.3 \%$ and $60.7 \%$, respectively, and bulk density was $0.16 \mathrm{~g} \cdot \mathrm{cm}^{-1}$ (NCSU porometer method; Fonteno et al., 1995). Pine bark elemental analyses results are reported in Table 1 . Additionally, initial pine bark saturated media extracts $(n=3)$ (Warncke, 1986) contained (in mg. $\mathrm{L}^{-1} \pm \mathrm{SE}$ ) less than $0.31 \mathrm{NH}_{4}-\mathrm{N}$, less than $0.12 \mathrm{NO}_{2}-\mathrm{N}, 0.12 \pm 0.02 \mathrm{NO}_{3}-\mathrm{N}$, $7.67 \pm 0.46 \mathrm{PO}_{4}-\mathrm{P}$ (i.e., OP), $25.4 \pm 1.51 \mathrm{~K}$, and $9.5 \pm 0.90 \mathrm{Cl}$. Electrical conductivity (EC) and $\mathrm{pH}$ values in saturated media extracts were $0.84 \pm 0.041 \mathrm{mS} \cdot \mathrm{cm}^{-1}$ and $4.9 \pm$ 0.04 , respectively. Methods used to determine ion concentrations, $\mathrm{EC}$, and $\mathrm{pH}$ have been described by Shreckhise et al. (2019).

On 22 Feb. 2017, pine bark was either nonamended (control) or amended with 2.97 $\mathrm{kg} \cdot \mathrm{m}^{-3}$ dolomite (FL), $0.89 \mathrm{~kg} \cdot \mathrm{m}^{-3}$ micronutrients (FM), or both dolomite and micronutrients (FLM). The dolomite was supplied as $50 \%$ pulverized dolomite $\left[94 \% \mathrm{CaCO}_{3}\right.$ equivalent (CCE); Old Castle Lawn and Garden, Thomasville, PA] and 50\% ground dolomite (97\% CCE; Rockydale Quarries Corporation, Roanoke, VA). The pulverized dolomite had $100 \%, 95 \%, 72 \%$, and $54 \%$ and the ground dolomite had $100 \%, 90 \%, 50 \%$, and $35 \%$ passing through $2.00-, 0.84-, 0.25-$, and $0.15-\mathrm{mm}$ mesh screens, respectively. Collectively, the dolomite mixture contained $21 \% \mathrm{Ca}$ and $22 \% \mathrm{Mg}$ (by weight). The granular micronutrient fertilizer (Micromax; ICL Specialty Fertilizers, Dublin, $\mathrm{OH}$ ) contained $6.00 \% \mathrm{Ca}, 3.00 \% \mathrm{Mg}, 12.00 \% \mathrm{~S}$, $0.10 \% \mathrm{~B}, 1.00 \% \mathrm{Cu}, 17.00 \% \mathrm{Fe}, 2.50 \%$ $\mathrm{Mn}, 0.05 \% \mathrm{Mo}$, and $1.00 \% \mathrm{Zn}$ derived from $\mathrm{CaMg}\left(\mathrm{CO}_{3}\right)_{2}, \mathrm{FeSO}_{4} \cdot 1 \mathrm{H}_{2} \mathrm{O}, \mathrm{MnSO}_{4}, \mathrm{ZnSO}_{4}$, $\mathrm{CuSO}_{4} \cdot 5 \mathrm{H}_{2} \mathrm{O}, \mathrm{Na}_{2} \mathrm{~B}_{4} \mathrm{O}_{7}$, and $\mathrm{Na}_{2} \mathrm{MoO}_{4} \cdot 2 \mathrm{H}_{2} \mathrm{O}$. Incorporation of dolomite and micronutrients into the substrate was accomplished by mixing for 5 min using a small cement mixer $\left(0.14 \mathrm{~m}^{3}\right.$ capacity; $\approx 23$ rotations per minute). Five 11.4-L aliquots of each of the four substrate mixes were amended with $28 \mathrm{~g}$ 
(i.e., $2.97 \mathrm{~kg} \cdot \mathrm{m}^{-3}$ pine bark) of a polymercoated 19N-2.6P-10.8K CRF (Harrell's LLC, Lakeland, FL). The CRF was a homogeneous 3- to 4-month release formulation (at $27{ }^{\circ} \mathrm{C}$ ) in which $\mathrm{N}, \mathrm{P}$, and $\mathrm{K}$ were derived from $\mathrm{NH}_{4} \mathrm{NO}_{3}, \mathrm{NH}_{4} \mathrm{H}_{2} \mathrm{PO}_{4}$, and $\mathrm{K}_{2} \mathrm{SO}_{4}$. The 20 substrate aliquots were each hand-mixed for $2 \mathrm{~min}$ to ensure equal distribution of CRF without damaging granules. The entirety of each aliquot of CRF-amended pine bark was then added to 20 respective 11.4 -L black plastic containers (C1200; Nursery Supplies, Chambersburg, PA) to plant one crape myrtle liner per container. During potting, the existing substrate was left in the liner root balls to minimize transplant stress. Plants were then hand-watered until leaching was observed.

Plants were grown for $93 \mathrm{~d}$ on four $353 \times$ $97 \times 76 \mathrm{~cm}(1 \times \mathrm{w} \times \mathrm{h})$ benches (five plants per bench) that each ran south to north in an environmentally controlled glass greenhouse with $80 \%$ photosynthetically active radiation transmission. Average daily maximum and minimum air temperatures measured using a digital temperature and humidity sensor (AcuRite 00619HD; Chaney Instrument Co., Lake Geneva, WI) were $25.4 \pm 0.46{ }^{\circ} \mathrm{C}$ and $14.2 \pm 0.39{ }^{\circ} \mathrm{C}$, respectively. Plants on the same benchtop were spaced $\approx 37 \mathrm{~cm}$ and benches were $\approx 46 \mathrm{~cm}$ apart. A randomized complete block design (RCBD) with four substrate treatments and five blocks was used to account for possible temperature and shading variations within the greenhouse caused by cooling pads. Blocks were arranged across benches south to north, with blocks 1 and 5 , respectively, furthest from and closest to the cooling pads.

To monitor the substrate temperature, a digital meat thermometer (AcuRite 00641W; Chaney Instrument Co.) with a $12.3-\mathrm{cm}$ probe was inserted horizontally through the container wall $\approx 11 \mathrm{~cm}$ above the container bottom of a randomly selected plant in blocks 1,3 , and 5 . Thermometers remained in the same three containers for the entirety of the study with the tip of each probe approximately in the center of the horizontal substrate profile. The substrate temperature was recorded on pour-through sampling dates before irrigation. The average substrate temperature, before irrigating, was $21.0 \pm 0.5^{\circ} \mathrm{C}$ over the course of the study.

Plants were monitored weekly for signs of pests and diseases. On day 8, all plants received $\approx 600 \mathrm{~mL}$ of cyantraniliprole (Mainspring GNL; $0.793 \mathrm{~mL} \cdot \mathrm{L}^{-1}$ ) drench to prevent infestation of common greenhouse pests (e.g., thrips, whitefly, scale). Fungus gnat larvae were controlled at $48 \mathrm{~d}$ after experiment initiation (DAI) by releasing 75,000 predatory mites (Hypoaspis miles; Biobest Sustainable Crop Management, Westerlo, Belgium) evenly divided among the 20 plants on the substrate surface.

Irrigation was controlled with GEVA 75 irrigation window controllers, each with a latch solenoid and hydraulic valve (G75-C1W-61; Baccara Automation Control, Bayswater, Victoria, AU), and applied via pressure-compensating spray stakes (202
$\left.\mathrm{mL} \cdot \mathrm{min}^{-1}\right)$ (01PSDS-PL1-B; Netafim, Fresno, CA). Plants received cyclic irrigation (two cycles per day; $\approx 3$ min between cycles) with tap water every 4 to $7 \mathrm{~d}$ until 63 DAI, and then every 2 to $3 \mathrm{~d}$ for the remainder of the study based on need. An additional pressure-compensating spray stake of the same flow rate was added to all containers at $20 \mathrm{DAI}$ to improve moisture distribution uniformity within each container. The irrigation volume was adjusted periodically as needed to achieve a target weekly leaching fraction (volume leached/volume applied) of 0.20 . The observed average leaching fraction, measured weekly, was $0.20 \pm 0.009(n=264)$ over the course of the study. Element concentrations in irrigation water were stable over time, with the following mean $(n=10)$ values $\left(\mathrm{mg} \cdot \mathrm{L}^{-1} \pm \mathrm{SE}\right): 13.0 \pm 0.38 \mathrm{Ca} ; 1.3 \pm$ $0.08 \mathrm{~K} ; 5.4 \pm 0.17 \mathrm{Mg} ; 10.3 \pm 0.22 \mathrm{Na} ; 0.1 \pm$ $0.02 \mathrm{Fe} ; 0.4 \pm 0.01 \mathrm{mg} \cdot \mathrm{L}^{-1} \mathrm{P} ; 2.0 \pm 0.04 \mathrm{~S}$; $0.2 \pm 0.02 \mathrm{Zn}$; and $50.8 \pm 2.03$ total alkalinity. Irrigation water $\mathrm{pH}$ and $\mathrm{EC}$ were $7.1 \pm 0.04$ $\mathrm{mS} \cdot \mathrm{cm}^{-1}$ and $0.15 \pm 0.002 \mathrm{mS} \cdot \mathrm{cm}^{-1}$, respectively.

Irrigation preceding pour-through extraction was accomplished by hand-pouring tap water through a diffuser to achieve $\approx 20 \%$ leaching. The diffuser was similar to that described by Shreckhise et al., (2019). This irrigation method was adopted before porewater extraction to further improve moisture uniformity of the substrate and ensure a consistent leaching fraction across treatments and repetitions by individually adjusting irrigation volume when necessary. On days 14 and 35 , and every $7 \mathrm{~d}$ thereafter through 91 DAI, substrate pore-water was extracted from each plant via the pour-through method (Wright, 1986). Pour-through extracts were attained by hand-pouring $300 \mathrm{~mL}$ of deionized (DI) water evenly over the substrate surface $1 \mathrm{~h}$ after irrigation and then collecting the $\approx 110 \mathrm{~mL}$ of subsequent leachate for analyses. An aliquot of each pore-water sample was analyzed for $\mathrm{pH}$ and $\mathrm{EC}$ within $4 \mathrm{~h}$ of pour-through extraction. The remainder of each sample was divided, prepared, and analyzed for ions, total dissolved $(<0.45 \mu \mathrm{m})$ elements, dissolved organic carbon (DOC), and total (nonfiltered) element concentrations in the same manner as that described by Shreckhise et al. (2019), except that porewater samples collected on a given date were analyzed individually (i.e., samples were not combined to form composite samples).

On day 93, plant shoots were severed level with the substrate surface and triplerinsed with both tap and distilled water. Approximately $80 \%$ of the loose substrate was shaken from roots and set aside for later collection of CRF granules to determine the proportion of the initial $\mathrm{N}, \mathrm{P}$, and $\mathrm{K}$ remaining. A tap water stream was used to remove the remaining substrate particles adhered to roots that could not be efficiently removed by hand. Then, shoots and roots were oven-dried at $65{ }^{\circ} \mathrm{C}$ until the weight remained constant. Shoot dry weights (SDW) and root dry weights (RDW) were weighed separately, summed to determine the total dry weight
(TDW), and then ground separately to a 0.5 mm particle size using a 3379-K35 Variable Speed Digital ED-5 Wiley Mill (Thomas Scientific, Swedesboro, NJ) set to $900 \mathrm{rpm}$. Ground samples were sent to Brookside Laboratories (New Bremen, $\mathrm{OH}$ ) for tissue nutrient analysis, during which plant samples were analyzed using a Thermo 6500 Duo ICP-OES (Thermo Fisher Scientific, Weltham, MA) after microwave-assisted digestion with nitric acid and hydrogen peroxide (T002 test package). Tissue nutrient concentrations were multiplied by the SDW or RDW values to calculate the $\mathrm{P}$ content. The total tissue $\mathrm{P}$ content (i.e., the sum of the $\mathrm{P}$ amounts in roots and shoots) was calculated to assess the relative PUE in plants among substrate treatments.

To determine the amount of $\mathrm{N}, \mathrm{P}$, and $\mathrm{K}$ remaining in CRF granules, $\approx 2 \mathrm{~g}$ of ovendried CRF from each replication within each treatment (totaling 20 samples weighing $2 \mathrm{~g}$ each) were collected from the postexperiment substrate. Because the CRF granules used in this study (Polyon) do not swell and, therefore, maintain a consistent volume over time, the postexperiment CRF was compared with fresh CRF based on volume. The volumes of each of the 20 postexperiment CRF samples as well as five 2-g samples of fresh CRF were determined by submerging granules in $5 \mathrm{~mL}$ of DI water contained in a 10 $\mathrm{mL}$ graduated cylinder and measuring displaced water volume $(\mathrm{mL})$. The DI water and $\mathrm{CRF}$ within the graduated cylinder were then poured into a $1-\mathrm{L}$ volumetric flask and brought to volume with DI water. The CRFDI water mixture was blended for 1-min using a 12-speed blender (006843-000-NP1; Oster, Boca Raton, FL) at the highest speed setting. An aliquot of the blended fertilizer solution was filtered using a $0.2-\mu \mathrm{m}$ polyvinylidene fluoride (PVDF) filter diluted $90 \%$ with DI water and then analyzed for $\mathrm{NO}_{3}$, $\mathrm{NO}_{2}, \mathrm{NH}_{4}, \mathrm{PO}_{4}$, and $\mathrm{K}$ concentrations using the ion chromatography system described by Shreckhise et al. (2019). The amount of each ion remaining in the CRF was calculated by dividing the amount $(\mathrm{mg})$ of ions in the postexperiment CRF by the amount $(\mathrm{mg})$ of ions in fresh $\mathrm{CRF}$ based on an equivalent CRF volume. Compared with the amounts in fresh CRF, $4 \%, 0.4 \%, 1 \%$, and $15 \%$ of the $\mathrm{NH}_{4}, \quad \mathrm{NO}_{3}, \quad \mathrm{PO}_{4}$, and $\mathrm{K}$, respectively, remained in the $\mathrm{CRF}$ at the end of the experiment, and no differences were observed among substrate treatments.

Visual MINTEQ (Gustafsson, 2013) was used to model chemical $\mathrm{P}$ speciation in leachate. Input parameters included $\mathrm{pH}$, DOC (NICA-Donnan model), $\mathrm{PO}_{4}{ }^{3-}, \mathrm{NH}_{4}{ }^{+}$, $\mathrm{NO}_{2}^{-}, \mathrm{NO}_{3}^{-}, \mathrm{B}(\mathrm{III}), \mathrm{Ca}^{2+}, \mathrm{Cl}^{-}, \mathrm{Cu}^{2+}, \mathrm{Fe}^{3+}, \mathrm{K}^{+}$, $\mathrm{Mg}^{2+}, \mathrm{Mn}^{2+}, \mathrm{Mo}(\mathrm{VI})$, sodium $\left(\mathrm{Na}^{+}\right), \mathrm{Ni}^{2+}$, $\mathrm{SO}_{4}{ }^{2-}$, and $\mathrm{Zn}^{2+}$ concentrations. Metals were assumed to be in their oxidized state. Carbonate $\left(\mathrm{CO}_{3}{ }^{2-}\right)$ concentrations were estimated based on the measured irrigation water alkalinity as well as $\mathrm{Ca}$ and $\mathrm{Mg}$ concentrations in leachate of substrates containing dolomite and/or micronutrients as an indicator of $\mathrm{CaMg}\left(\mathrm{CO}_{3}\right)_{2}$ dissolution. 
Saturation index (SI) values were used to interpret the degree of saturation in solutions with regard to solid phases. Saturation indices were calculated as $\log \left(\mathrm{IAP} / \mathrm{K}_{\mathrm{sp}}\right)$, where IAP is the ion activity product and $\mathrm{K}_{\mathrm{sp}}$ is the solubility product constant. For a given compound, SI values of $<0,0$, or $>0$ indicate that the solution is undersaturated, saturated, or supersaturated, respectively, with regard to the solid phase.

Statistical analysis. Before analyses, Ca and $\mathrm{Mn}$ values were $\log$ and Johnsontransformed (Johnson, 1949), respectively, to correct for heteroscedasticity and nonnormality. All data collected in pourthrough extracts over time were subjected to a two-way repeated measures analysis of variance (ANOVA) with one betweensubjects factor, substrate (control, FL, FM, and FLM), and repeated measures factor, time $(14,35,42,48,56,63,70,77,84$, and $91 \mathrm{DAI})$. The repeated measures analysis was accomplished via covariance structure modeling (Wolfinger, 1993), in which the most appropriate covariance structure was selected by fitting data to various homogeneous and heterogenous covariance structures available in JMP Pro 14 (SAS Institute Inc., Cary, NC) and subsequently comparing corrected Akaike information criterion $\left(\mathrm{AIC}_{\mathrm{c}}\right)$ values. According to lowest $\mathrm{AIC}_{\mathrm{c}}$ values, the firstorder autoregressive (AR[1]) covariance structure was used for all repeated measures analyses. Except when analyzing TDW and P tissue content, the random block effect was removed from the analysis because it did not improve the model fit. When the substrate $x$ time interaction was significant, simple ef-

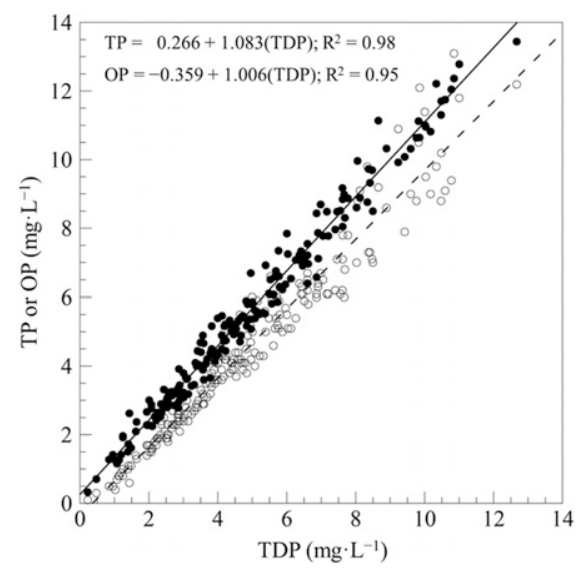

Fig. 1. Linear relationship between total dissolved phosphorus (TDP) and total phosphorus (TP; filled circles) or orthophosphate phosphorus (OP; open circles) in pour-through extracts collected approximately weekly for $91 \mathrm{~d}$ from containerized Lagerstroemia 'Natchez' grown in pine bark with $2.97 \mathrm{~kg} \cdot \mathrm{m}^{-3}$ of a polymercoated $19 \mathrm{~N}-2.6 \mathrm{P}-10.8 \mathrm{~K}$ controlled-release fertilizer and one of the following amendment treatments: no amendments (control); 2.97 $\mathrm{kg} \cdot \mathrm{m}^{-3}$ dolomite (FL); $0.89 \mathrm{~kg} \cdot \mathrm{m}^{-3}$ micronutrient fertilizer (FM); or both dolomite and micronutrient fertilizer (FLM). Equations were developed from data pooled across time and substrate treatments $(\mathrm{n}=198)$. fects were analyzed via Dunnett's method or Tukey's honestly significant difference. Substrate effects on dry weight and tissue nutrient content were analyzed using one-way ANOVA, and post-hoc means separation was accomplished using Tukey's honestly significant difference. Saturation indices for each sampling date and treatment were determined to be significantly greater than 0 (i.e., supersaturated) using a one-sample $t$ test with the hypothesized mean set to " 0 ". The substrate effect on the linear relationship between TDP (x) and OP (y) or TP (y) was assessed by determining the significance of the substrate $\times$ TDP interaction. The correlation between PP and TDP was analyzed using the Pearson correlation coefficient $(r)$. All data were processed using JMP Pro 14 (SAS Institute Inc.), and figures were created using KaleidaGraph 4.5.3 (Synergy Software, Reading, PA).

\section{Results}

Substrate effects on P fractions. The total dissolved $P$ had a strong linear relationship with OP and TP (Fig. 1). In the linear models equating TDP to OP or TP, the substrate $\times$ TDP interaction terms were not significant $(P=0.1948$ and 0.0650 , respectively); therefore, they were removed from both models. When pooled across substrates and time, OP contributed $93 \%$ of TDP and TDP contributed $87 \%$ of TP (Table 3 ). In the control, FL, FM, and FLM substrates, TP comprised 79\%, $89 \%, 79 \%$, and $75 \%$ OP, respectively, when pooled over time.

The main effects of substrate and time and the substrate $\times$ time interaction were significant for both OP and TDP (Table 2). The main effects of substrate on OP and TDP pooled over time are presented in Table 3 . Both OP and TDP concentrations in FL were equivalent to those in the control within the respective fractions, whereas FM and FLM had $55 \%$ and $140 \%$ lower TDP and $65 \%$ and $150 \%$ lower OP concentrations, respectively, than FL. Orthophosphate P and TDP concentrations in FM were $32 \%$ and $35 \%$, respectively, lower than those in the control, whereas concentrations in FLM were $\approx 56 \%$ lower than those in the control for these two fractions. Pooled TDP concentrations in FLM were also $36 \%$ lower than those in the FM treatment, whereas OP concentrations in FLM were not different from those in FM.

Because treatments had similar effects on TDP and OP, and because TDP values were used to calculate PP, simple effects of treatments at each sampling time are reported only for TDP (Fig. 2). From 14 to 42 DAI, pore-water TDP concentrations decreased in the control, FL, and FLM, but they stayed the same in FM. Thereafter, TDP concentrations in all treatments increased until reaching a maximum between 56 and 70 DAI; then, they decreased for the remainder of the study. Total dissolved $\mathrm{P}$ concentrations in the FL treatment were higher than or equal to those of the control, except at 14 DAI, during which TDP concentrations were $26 \%$ lower in FL than in the control. In the FM substrate,
Table 2. Degrees of freedom (df), F-values, and $P$ values for the analysis of variance (ANOVA) to determine significant effects of substrate treatment, time ( 1 to $91 \mathrm{DAI}$ ), and the substrate $\times$ time interaction on orthophosphate phosphorus (OP) total dissolved phosphorus (TDP), particulate phosphorus (PP), total phosphorus (TP), $\mathrm{pH}$, calcium $(\mathrm{Ca})$, and manganese $(\mathrm{Mn})$ in pour-through extracts of container-grown Lagerstroemia 'Natchez'. Substrates were amended with $2.97 \mathrm{~kg} \cdot \mathrm{m}^{-3}$ of a polymer-coated $19 \mathrm{~N}-2.6 \mathrm{P}-10.8 \mathrm{~K}$ controlledrelease fertilizer (CRF) and either additional amendment (control), $2.97 \mathrm{~kg} \cdot \mathrm{m}^{-3}$ dolomite (FL), $0.89 \mathrm{~kg} \cdot \mathrm{m}^{-3}$ micronutrient fertilizer (FM), or both dolomite and micronutrient fertilizer (FLM).

\begin{tabular}{|c|c|c|c|}
\hline ANOVA source & $\mathrm{df}$ & $\mathrm{F}$ value & $P$ value \\
\hline \multicolumn{4}{|l|}{$\mathrm{OP}$} \\
\hline Substrate & 3 & 27.9 & $<0.0001$ \\
\hline Time & 9 & 49.6 & $<0.0001$ \\
\hline Substrate $\times$ time & 27 & 7.3 & $<0.0001$ \\
\hline \multicolumn{4}{|l|}{ TDP } \\
\hline Substrate & 3 & 24.5 & $<0.0001$ \\
\hline Time & 9 & 32.1 & $<0.0001$ \\
\hline Substrate $\times$ time & 27 & 3.8 & $<0.0001$ \\
\hline \multicolumn{4}{|l|}{$\mathrm{PP}$} \\
\hline Substrate & 3 & 3.1 & 0.0508 \\
\hline Time & 9 & 12.3 & $<0.0001$ \\
\hline Substrate $\times$ time & 27 & 2.2 & 0.0063 \\
\hline \multicolumn{4}{|l|}{$\mathrm{TP}$} \\
\hline Substrate & 3 & 23.2 & $<0.0001$ \\
\hline Time & 9 & 44.4 & $<0.0001$ \\
\hline Substrate $\times$ time & 27 & 5.0 & $<0.0001$ \\
\hline \multicolumn{4}{|l|}{$\mathrm{pH}$} \\
\hline Substrate & 3 & $3,506.4$ & $<0.0001$ \\
\hline Time & 9 & 30.6 & $<0.0001$ \\
\hline Substrate $\times$ time & 27 & 15.6 & $<0.0001$ \\
\hline \multicolumn{4}{|l|}{$\mathrm{Ca}$} \\
\hline Substrate & 3 & 188.9 & $<0.0001$ \\
\hline Time & 9 & 24.9 & $<0.0001$ \\
\hline Substrate $\times$ time & 27 & 13.0 & $<0.0001$ \\
\hline \multicolumn{4}{|l|}{$\mathrm{Mn}$} \\
\hline Substrate & 3 & 525.1 & $<0.0001$ \\
\hline Time & 9 & 49.9 & $<0.0001$ \\
\hline Substrate $\times$ time & 27 & 10.3 & $<0.0001$ \\
\hline
\end{tabular}

TDP concentrations were $68 \%, 46 \%$, and $23 \%$ lower than those in the control at 14 , 35 , and $56 \mathrm{DAI}$, respectively, and were equivalent to those in the control at all other sampling dates. Total dissolved P concentrations in the FLM treatment were between $43 \%$ and $73 \%$ lower than those of the control at all sampling dates for the first $63 \mathrm{~d}$ of the study and at $91 \mathrm{DAI}$, with greatest differences occurring at 14 to 42 DAI.

The main effect of time and the substrate $X$ time interaction were significant for PP; however, the main effect of substrate was not (Table 2). Simple effects of substrates on PP concentrations are illustrated in Fig. 2. Particulate $\mathrm{P}$ concentrations were affected by substrate treatments only on the first two sampling days. At 14 DAI, PP concentrations in FM and FLM were $71 \%$ and $45 \%$, respectively, lower than those in the control; at 35 DAI, PP concentrations in FM were $72 \%$ lower than those of the control. Particulate $\mathrm{P}$ concentrations in FL, FM, and FLM were equivalent to those in the control on all sampling dates after 35 DAI. The correlation between PP and TDP was analyzed to 
Table 3. Pore-water concentrations of orthophosphate phosphorus (OP), total dissolved phosphorus (TDP), particulate phosphorus (PP), and total phosphorus (TP) pooled over sampling dates $(\mathrm{n}=200)$ and shoot dry weight $(\mathrm{SDW})$, root dry weight $(\mathrm{RDW})$, final total dry weight $(\mathrm{TDW})$, tissue phosphorous $(\mathrm{P})$ content, and $\mathrm{P}$ uptake efficiency (PUE) $(\mathrm{n}=5)$ of containerized Lagerstroemia 'Natchez' grown for $91 \mathrm{~d}$ in a pine bark substrate amended with $2.97 \mathrm{~kg} \cdot \mathrm{m}^{-3}$ of a polymercoated $19 \mathrm{~N}-2.6 \mathrm{P}-10.8 \mathrm{~K}$ controlled-release fertilizer and no additional amendment (control), $2.97 \mathrm{~kg} \cdot \mathrm{m}^{-3}$ dolomite $(\mathrm{FL}), 0.89 \mathrm{~kg} \cdot \mathrm{m}^{-3} \mathrm{micronutrient}$ fertilizer (FM), or both dolomite and micronutrient fertilizer (FLM).

\begin{tabular}{|c|c|c|c|c|c|c|c|c|c|}
\hline Substrate & OP $\left(\mathrm{mg} \cdot \mathrm{L}^{-1}\right)$ & TDP $\left(\mathrm{mg} \cdot \mathrm{L}^{-1}\right)$ & PP (mg. $\left.\mathrm{L}^{-1}\right)$ & TP $\left(\mathrm{mg} \cdot \mathrm{L}^{-1}\right)$ & SDW (g) & RDW (g) & TDW (g) & Tissue P (mg) & $\mathrm{PUE}^{2}$ \\
\hline FM & $3.7 \mathrm{~b}$ & $4.2 \mathrm{~b}$ & 0.53 & $4.7 \mathrm{~b}$ & $65.4 \mathrm{a}$ & $21.4 \mathrm{a}$ & $86.8 \mathrm{a}$ & $194.2 \mathrm{ab}$ & 0.29 \\
\hline FLM & $2.5 \mathrm{~b}$ & $2.7 \mathrm{c}$ & 0.58 & $3.3 \mathrm{c}$ & $76.9 \mathrm{a}$ & $18.3 \mathrm{a}$ & $95.3 \mathrm{a}$ & $210.8 \mathrm{a}$ & 0.33 \\
\hline
\end{tabular}

${ }^{\mathrm{z}} \mathrm{PUE}=(\mathrm{mg} \mathrm{P}$ in plant tissue $) \div(\mathrm{mg}$ P released from CRF $)$.

${ }^{\mathrm{y}}$ Means followed by the same letter within columns are not significantly different according to Tukey's honestly significant difference ( 0.05$)$.

determine if relatively high PP concentrations corresponded with relatively low TDP concentrations. Particulate P and TDP concentrations had a moderate positive correlation $(r=0.471 ; P<0.0001)$. Similar to TDP, PP concentrations in the control and all treatments peaked at 70 DAI before declining for the remainder of the study.

The main effects of substrate and time and the substrate $x$ time interaction on TP were significant (Table 2). The main effect of substrate on TP is presented in Table 3 . Similar to results described for OP and TDP, pore-water TP concentrations in the control and FL treatment were equivalent, whereas in FM and FLM, TP concentrations were $36 \%$ and $56 \%$, respectively, lower than those in the control. Total $\mathrm{P}$ concentrations in FLM were also 31\% lower than those in FM. Simple effects of substrates on TP at each sampling time are presented in Fig. 2. Total P concentrations in FL were $26 \%$ lower than those in the control at $14 \mathrm{DAI}$ and $58 \%$ and $103 \%$ higher than those in the control at 77 and 91 DAI, respectively. At all other sampling dates, TP concentrations in the control and FL were equivalent. Total $\mathrm{P}$ concentrations in FM were the same as those in the control at all sampling dates except 14 and 35 DAI, during which TP concentrations in FM were $69 \%$ and $49 \%$, respectively, lower than those in the control. In the FLM treatment, TP concentrations were $40 \%$ to $73 \%$ lower than those in the control at 14 to 63 DAI.

Modeling. Two P species were supersaturated with regard to their solid phases according to SI values calculated by Visual MINTEQ manganese hydrogen phosphate $\left(\mathrm{MnHPO}_{4}\right)$ and hydroxyapatite $\left[\mathrm{Ca}_{5}\left(\mathrm{PO}_{4}\right)\right.$ $\left.{ }_{3} \mathrm{OH}\right]$ (Table 4). Saturation indices for $\mathrm{MnHPO}_{4}$ were significantly higher than 0 (i.e., supersaturated with regard to the solid phase) on all sampling dates and in all treatments, including the control. Saturation indices were highest in FLM from 14 to 63 DAI, and in FLM or FL for the remainder of the study. The lowest SI values for $\mathrm{MnHPO}_{4}$ were generally in the control or FM substrates. Saturation indices for $\mathrm{Ca}_{5}\left(\mathrm{PO}_{4}\right)_{3} \mathrm{OH}$ in FL were greater than 0 and generally higher than SI values in FLM from 42 to 70 DAI. In FLM, SI values for $\mathrm{Ca}_{5}\left(\mathrm{PO}_{4}\right)_{3} \mathrm{OH}$ were greater than 0 only at 70 DAI. In extracts from the control and $\mathrm{FM}$, the $\mathrm{Ca}_{5}$ $\left(\mathrm{PO}_{4}\right)_{3} \mathrm{OH}$ solid phase was undersaturated on all sampling dates.
$\mathrm{pH}$, calcium, and manganese. Substrate effects on pore-water $\mathrm{pH}, \mathrm{Ca}$, and $\mathrm{Mn}$ were analyzed to facilitate an interpretation of the predicted occurrence of $\mathrm{MnHPO}_{4}$ and $\mathrm{Ca}_{5}$ $\left(\mathrm{PO}_{4}\right)_{3} \mathrm{OH}$ solid phases. Because the substrate and time main effects and the substrate $\times$ time interaction were significant for $\mathrm{pH}, \mathrm{Mn}$, and $\mathrm{Ca}$ (Table 2), the simple effects of substrate were examined at each level of time (Fig. 3). Despite the significant substrate $\times$ time interaction for $\mathrm{pH}$, pore-water $\mathrm{pH}$ varied by $\leq 0.3,0.6$, 0.5 , and 0.7 units in the control, FL, FM, and FLM, respectively, over the course of the study. When averaged over time, pore-water $\mathrm{pH}$ values of the control, FL, FM, and FLM were $4.3 \pm 0.02,6.4 \pm 0.03,3.7 \pm 0.02$, and $6.2 \pm$ 0.03 , respectively.

Pore-water Mn concentrations were highest in FM at all sampling dates, ranging from 18.4 to $1.5 \mathrm{mg} \cdot \mathrm{L}^{-1}$ at $14 \mathrm{DAI}$ and $77 \mathrm{DAI}$, respectively (Fig. 3). Manganese concentrations in FLM were less than one-tenth of those in FM and decreased over the course of the study from $4.1 \mathrm{mg} \cdot \mathrm{L}^{-1}$ at 14 DAI to 0.1 $\mathrm{mg} \cdot \mathrm{L}^{-1}$ at 91 DAI. In the control and FM substrates, Mn concentrations were consistently less than 0.6 and $0.05 \mathrm{mg} \cdot \mathrm{L}^{-1}$, respectively, with higher Mn concentrations in the control at all sampling dates.

Calcium concentrations in the control were relatively constant over time, fluctuating between maximum and minimum concentrations of 14 and $6 \mathrm{mg} \cdot \mathrm{L}^{-1}$, respectively (Fig. 3). Calcium concentrations in FM were generally equivalent to those in FLM. In FM and FLM, Ca concentrations decreased from 111 or $85 \mathrm{mg} \cdot \mathrm{L}^{-1}$, respectively, at $14 \mathrm{DAI}$ to $16 \mathrm{mg} \cdot \mathrm{L}^{-1}$ at $77 \mathrm{DAI}$, and then increased for the remainder of the study. In contrast, $\mathrm{Ca}$ concentrations in FL increased from 15 $\mathrm{mg} \cdot \mathrm{L}^{-1}$ at $14 \mathrm{DAI}$ to a maximum concentration of $32 \mathrm{mg} \cdot \mathrm{L}^{-1}$ at $70 \mathrm{DAI}$, and then decreased to $20 \mathrm{mg} \cdot \mathrm{L}^{-1}$ by $91 \mathrm{DAI}$.

Plant biomass and tissue phosphorus. Plants grown in FM or FLM had the highest SDW, RDW, and TDW among the treatments and control (Table 3). Compared with plants grown in FLM, SDW, RDW, and TDW were $29 \%$ to $35 \%$ lower for plants grown in the control and $51 \%$ to $53 \%$ lower for plants grown in FL. The SDW and TDW of plants grown in FL were $\approx 28 \%$ lower than those in plants grown in the control, whereas the RDW was the same in these two treatments. The total $\mathrm{P}$ content in plant tissue (i.e., shoots and roots) was $28 \%$ higher in plants
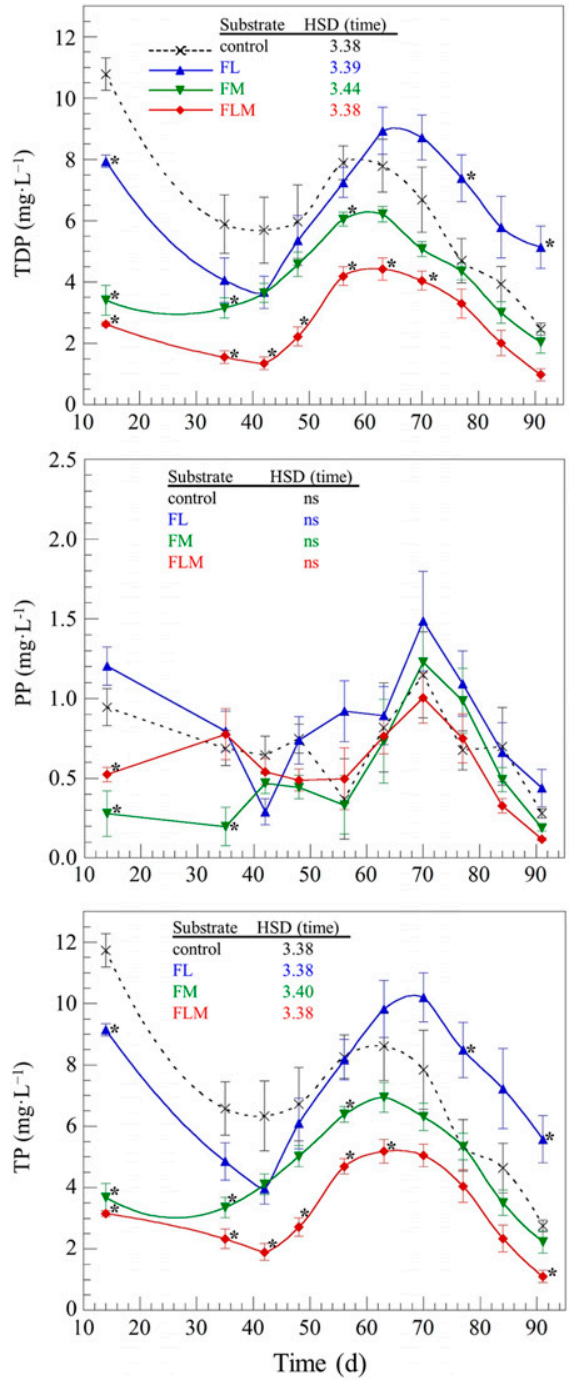

Fig. 2. Effects of substrate treatments on total dissolved phosphorus (TDP), particulate phosphorus (PP), and total phosphorus (TP) concentrations over time in pour-through extracts of containerized Lagerstroemia 'Natchez' grown for $91 \mathrm{~d}$ in a pine bark substrate amended with $2.97 \mathrm{~kg} \cdot \mathrm{m}^{-3}$ of a polymer-coated $19 \mathrm{~N}-2.6 \mathrm{P}-10.8 \mathrm{~K}$ controlled-release fertilizer (CRF) and either no amendment (control), $2.97 \mathrm{~kg} \cdot \mathrm{m}^{-3}$ dolomite (FL), $0.89 \mathrm{~kg} \cdot \mathrm{m}^{-3}$ micronutrient fertilizer (FM), or both dolomite and micronutrient fertilizer (FLM). Asterisks next to means indicate a significant difference from control within the corresponding sampling date according to Dunnett's test $(\mathrm{n}=5 ; P<$ 0.05 ). Tukey's honestly significant difference (HSD) values enable comparisons of concentrations over time within the corresponding treatment. Vertical bars represent the SEM. 
Table 4. Saturation indices calculated by Visual MINTEQ for phosphorus (P) species saturated with regard to the solid phase (means $>0$ ) in pour-through extracts collected at various times over the course of $91 \mathrm{~d}$ from containerized Lagerstroemia 'Natchez' grown in a pine bark substrate amended with $2.97 \mathrm{~kg} \cdot \mathrm{m}^{-3}$ of a polymer-coated $19 \mathrm{~N}-2.6 \mathrm{P}-10.8 \mathrm{~K}$ controlled-release fertilizer (CRF). In addition to CRF, substrate treatments included the following: no amendment (control); $2.97 \mathrm{~kg} \cdot \mathrm{m}^{-3}$ dolomite (FL); $0.89 \mathrm{~kg} \cdot \mathrm{m}^{-3}$ micronutrient fertilizer (FM); or both dolomite and micronutrient fertilizer (FLM).

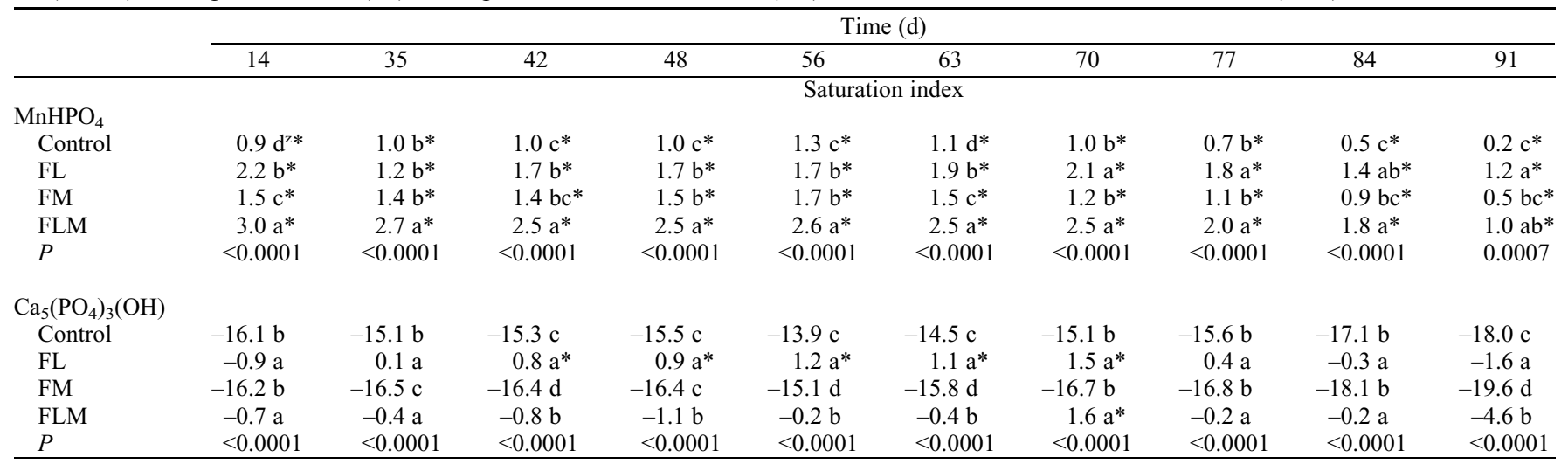

${ }^{\mathrm{z}}$ Means followed by the same letter within columns are not significantly different according to Tukey's honestly significant difference ( 0.05$)$.

*Indicates significantly $>0$ at the 0.05 level according to a one-sample $t$ test with the hypothesized mean set to " 0 ".

grown in FLM compared with FL, and equivalent among plants grown in the control, FM, or FLM substrates. Because CRF-P release was the same across treatments, the effects of treatments on PUE were interpreted in the same way as those of tissue $\mathrm{P}$ content, with the highest PUE in plants grown in the control, FM, and FLM and lowest in those grown in FL.

\section{Discussion}

The total dissolved $\mathrm{P}$ concentrations (i.e., $\mathrm{P}$ concentration in filtered solutions determined via ICP-AES) are routinely measured by analytical laboratories because ICP-AES can conveniently measure all essential plant nutrients, except N, simultaneously. However, because TDP includes dissolved organic $\mathrm{P}$ and colloidal $\mathrm{P}$ in addition to $\mathrm{OP}$ (Van Moorleghem et al., 2011), substrate extract samples are often also analyzed colorimetrically (e.g., molybdate blue method) (Murphy and Riley, 1962) or via ion chromatography to provide a more accurate estimate of plant-available $P$ concentrations. Given that the linear relationship between OP (y) and TDP (x) has a slope of $\approx 1$ and a small y-intercept $(-0.359)$, from a practical standpoint, TDP is a good proxy for OP in pour-through samples, regardless of the presence of dolomite or micronutrient amendments. Hence, analyzing filtered samples via ion chromatography or colorimetry in addition to ICP-AES is unnecessary for interpreting the plant availability of $P$ in pour-through extracts from pine bark substrates. Handreck (1996) came to a similar conclusion when comparing TDP to OP concentrations in $2 \mathrm{mM}$ diethylenetriaminepentaacetic acid (DTPA) extracts of a pine bark substrate amended with various rates of $\mathrm{FeSO}_{4}$, citing the following equation: $\mathrm{TDP}=0.237+$ $1.03(\mathrm{OP})\left(R^{2}=0.98\right)$.

Total $\mathrm{P}$ is often a more informative $\mathrm{P}$ fraction than TDP or OP from an environmental standpoint because many species of
PP in runoff can become labile for algae consumption in receiving waters (Okubo et al., 2012; Uusitalo et al., 2003). However, analyzing aqueous samples for TP is a laborious process relative to that of TDP or OP, because TP determination often requires a digestion step to solubilize any particulate $\mathrm{P}$ in the sample. The strong linear relationship between TDP and TP $\left(R^{2}=0.98\right)$ and the absence of a TDP $\times$ substrate interaction suggest that TDP is a reliable predictor of $\mathrm{TP}$, regardless of whether sulfate-based micronutrients and dolomite are added to the substrate. Million et al. (2007 b) reported a similar relationship between OP and TP in runoff samples from container-grown Viburnum odoratissimum (L.) Ker-Gawl: TP = $0.03+1.10(\mathrm{OP})\left(R^{2}=0.99\right)$.

Approximately $75 \%$ of TP measured in pour-through extracts from FLM was OP. Hence, in studies that could not account for $43 \%$ to $84 \%$ of applied fertilizer $\mathrm{P}$ in the plant, leachate, and substrate (McGinnis et al., 2009; Owen et al., 2008; Ristvey et al., 2004; Tyler et al., 1996a; Warren et al., 2001), a portion of the unrecovered $P$ was likely in the leachate in a form other than OP. This contention is supported by Shreckhise et al. (2019), who reported that, depending on the sampling date, $4 \%$ to $69 \%$ of TP was OP in leachate of fallow pine bark columns amended with the same dolomite and micronutrient products used in the current study.

Substrate treatment effects on pore-water OP, TDP, and TP have similar interpretations because TDP and TP consisted predominantly of OP and, as a result, the responses of TDP and TP to substrate treatments reflect the response of OP. Our data indicate that amending pine bark with micronutrients can reduce pour-through $\mathrm{P}$ concentrations and increase plant biomass without inhibiting the amount of $\mathrm{P}$ absorbed by the plants. The overall 35\% lower TDP concentrations in FM compared with the control can be attributed to reductions observed at the first two sam- pling events. Shreckhise et al. (2019) also reported that the effects of micronutrients added to fallow pine bark columns on leachate $\mathrm{OP}, \mathrm{TDP}$, and TP were short-term, citing that micronutrients had no effects on these $\mathrm{P}$ fractions by the ninth irrigation event. Although the effects of micronutrients on $\mathrm{P}$ solubility in pine bark appear to be brief relative to the duration of a growing season, the period during which they most effectively reduce TDP leaching corresponds to the period of greatest leaching losses (Million et al., 2007a). Lower pore-water OP and TDP concentrations in FM compared with the control could not be attributed to precipitation because SI values indicated $\mathrm{Ca}_{5}\left(\mathrm{PO}_{4}\right)_{3} \mathrm{OH}$ was consistently undersaturated in both substrates and $\mathrm{MnHPO}_{4}$ SI values in the control and FM were generally equivalent. A possible explanation for greater TDP retention in FM compared with the control is that the pine bark was impregnated with Fe from the micronutrient amendment $(16 \% \mathrm{Fe})$, which subsequently increased the $\mathrm{P}$ adsorption capacity of the substrate. Cationization of organic materials via loading them with $\mathrm{Fe}$ from $\mathrm{Fe}$ salts has been shown to increase the $\mathrm{P}$ adsorption capacity of coir pith from 4.35 to $22.04 \mathrm{mg} \cdot \mathrm{g}^{-1} \mathrm{P}$ (Krishnan and Haridas, 2008) and sphagnum moss extract residue from 0.14 to $13 \mathrm{mg} \cdot \mathrm{g}^{-1}$ (Zhang et al., 2018). Both studies reported maximum $\mathrm{P}$ adsorption capacities at a $\mathrm{pH}$ of 3 . Additional research is needed to investigate this possible fate of $\mathrm{P}$ in container substrates and whether the sorbed $\mathrm{P}$ is labile.

The pooled OP, TDP, and TP concentrations in FL were not different from those in the control because $\mathrm{P}$ concentrations in FL were initially lower (14 DAI) and eventually higher (77 and $91 \mathrm{DAI}$ ) than those in the control. At 14 DAI, the predicted precipitation of $\mathrm{MnHPO}_{4}$ was greater in FL than in the control, suggesting that precipitation of TDP with Mn may have contributed to the initially lower pore-water $\mathrm{P}$ concentrations in FL. Adsorption or surface precipitation of TDP 

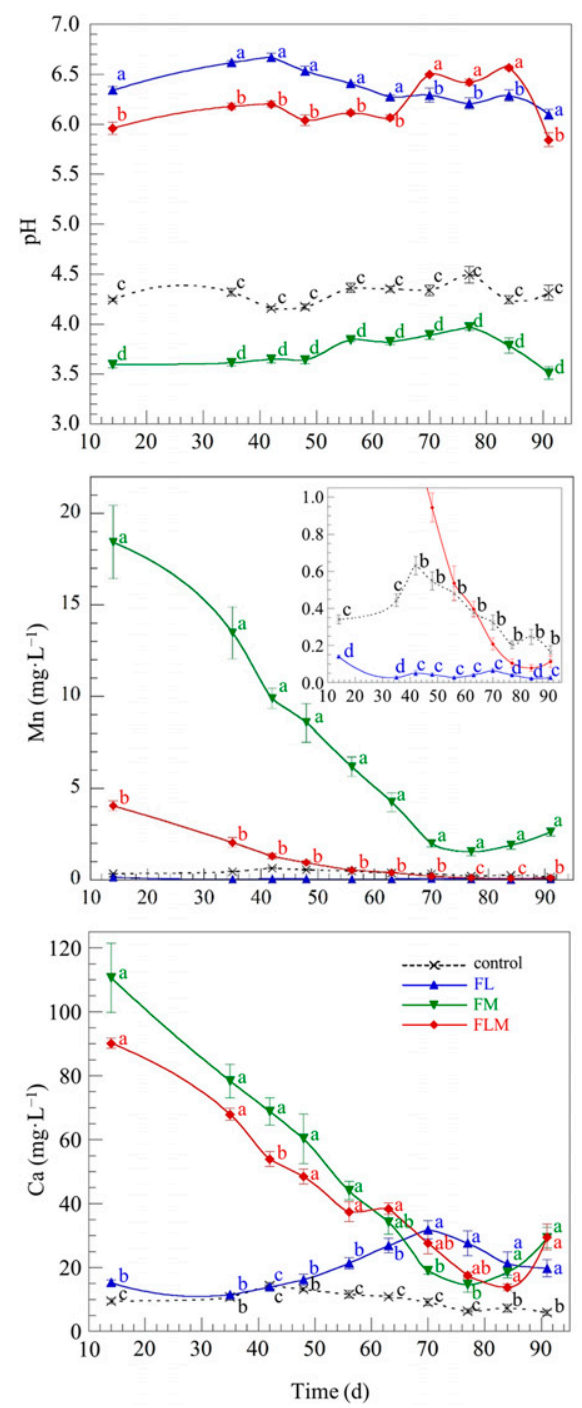

Fig. 3. Effects of substrate treatments on $\mathrm{pH}$, manganese $(\mathrm{Mn})$, and calcium $(\mathrm{Ca})$ over time in pour-through extracts of containerized Lagerstroemia 'Natchez' grown for $91 \mathrm{~d}$ in a pine bark substrate amended with $2.97 \mathrm{~kg} \cdot \mathrm{m}^{-3}$ of a polymer-coated $19 \mathrm{~N}-2.6 \mathrm{P}-10.8 \mathrm{~K}$ controlled-release fertilizer (CRF). Substrate treatments included the following: no amendment (control); $2.97 \mathrm{~kg} \cdot \mathrm{m}^{-3}$ dolomite (FL); 0.89 $\mathrm{kg} \cdot \mathrm{m}^{-3}$ micronutrient fertilizer (FM); or both dolomite and micronutrient fertilizer (FLM). Different vertically aligned letters next to means indicate significant difference among substrate treatments (control, FL, FM, and FLM) within the corresponding sampling date according to Tukey's honestly significant difference (HSD) $(\mathrm{n}=5 ; P<0.01)$. Nontransformed values are reported. Vertical bars represent the SEM.

onto the dolomite mineral surface may have also had a role in the initial (14 DAI) TDP retention in FL because dolomite has been shown to have a $\mathrm{P}$ sorption capacity ranging from 4.8 to $52.9 \mathrm{mg} \cdot \mathrm{g}^{-1} \mathrm{P}$ (Karaca et al., 2004; Xu et al., 2014; Yuan et al., 2015). When comparing pooled TDP concentrations in FL to those in FLM, lower TDP concentrations in FLM were partially due to relative differences in $\mathrm{P}$ amounts absorbed by plants, as indicated by the $28 \%$ higher tissue $\mathrm{P}$ amounts in plants grown in FLM compared with FL.

Because the tissue $\mathrm{P}$ content in FM was the same as that in FLM, the lower porewater TDP concentrations in FLM were not a result of differences in plant uptake of $\mathrm{P}$. Saturation indices for $\mathrm{MnHPO}_{4}$ in $\mathrm{FLM}$ were $55 \%$ to $103 \%$ higher than those in FM at all sampling dates; hence, a greater degree of $\mathrm{MnHPO}_{4}$ precipitation is one possible explanation for lower pore-water TDP concentrations in FLM compared with FM. Because SI values for $\mathrm{Ca}_{5}\left(\mathrm{PO}_{4}\right)_{3} \mathrm{OH}$ were positive only at one of the 10 sampling dates, the precipitation of $\mathrm{Ca}_{5}\left(\mathrm{PO}_{4}\right)_{3} \mathrm{OH}$ was unlikely a sink for TDP in FLM. In contrast, Shreckhise et al. (2019) reported SI values of as high as 7.3 for $\mathrm{Ca}_{5}\left(\mathrm{PO}_{4}\right)_{3} \mathrm{OH}$ in leachate from fallow pine bark columns containing dolomite and micronutrient amendments. The lower SI values for $\mathrm{Ca}_{5}\left(\mathrm{PO}_{4}\right)_{3} \mathrm{OH}$ in the current study were likely a result of lower $\mathrm{pH}$ values; in the current study, the $\mathrm{pH}$ was $\approx 6.2$, but it was $>7$ in another study (Shreckhise et al., 2019). As was previously mentioned for the singleamendment treatments, adsorption of TDP by dolomite or pine bark impregnated with $\mathrm{Fe}$ from the micronutrients also may have contributed to the lower TDP concentrations in FLM compared with those in all other substrates.

A possible explanation for equivalent $\mathrm{P}$ uptake among plants in FM and the control is that despite the lower concentrations of available $\mathrm{P}$ in substrate pore-water for plants in FM, OP concentrations were still sufficiently high that uptake was not limited. As was illustrated by Timmer (1991), increasing the supply of a limiting plant nutrient initially results in a relatively rapid increase in the plant tissue content of that nutrient until it is no longer limiting. Increasing the supply of a nonlimiting nutrient results in minor increases of that nutrient in plant tissue. In the current study, we suspect that $\mathrm{P}$ was nonlimiting in FM because plants grown in this substrate had higher biomass than those grown in the control. Accordingly, differences in pore-water OP concentrations among treatments expectedly had a minor impact on P tissue content. Another possible reason why plants grown in the control and FM substrates had similar tissue $\mathrm{P}$ content is that TDP concentrations were lower in FM than in the control only at 14,35 , and 56 DAI. Therefore, TDP concentrations in these two treatments were the same during the period when plants were largest and, therefore, expectedly had higher $\mathrm{P}$ absorption rates compared with those earlier in the trial (Tanaka et al., 1974; Xu et al., 2004). The effect of $\mathrm{pH}$ on $\mathrm{P}$ uptake is a third explanation for equivalent $\mathrm{P}$ amounts in the plant tissue of plants grown in FM or the control. The consistently lower $\mathrm{pH}$ values in $\mathrm{FM}(\approx 3.7)$ compared with those in the control $(\approx 4.3)$ may have hindered OP uptake for plants in FM, partially offsetting the greater biomass of plants in FM compared with those in the control. Similarly, when growing six plant taxa in solution culture, Islam et al. (1980) found that tissue $\mathrm{P}$ concentrations increased with the increasing solution $\mathrm{pH}$ in the range of 3.3 to 5.5. Phosphorus uptake efficiency values in the current study $(0.25-0.33)$ were within the range of 0.07 to 0.62 reported in other studies in which containerized woody plants were grown in a pine bark-based substrate with CRF (McGinnis et al., 2009; Owen et al., 2008; Tyler et al., 1996a, 1996b; Warren et al., 2001).

The SDW, RDW, and total dry weight data indicate that $0.89 \mathrm{~kg} \cdot \mathrm{m}^{-3}$ of the micronutrient amendment used in this study equally improves the growth of crape myrtle in limed and nonlimed pine bark substrate, whereas liming with $2.97 \mathrm{~kg} \cdot \mathrm{m}^{-3}$ dolomite limits crape myrtle growth if micronutrient fertilizer is absent. Consistent with our findings, in a review of dolomite effects on plant growth in pine bark substrate, Altland and Jeong (2016) concluded that a supplemental micronutrient fertilizer is generally necessary in substrates containing dolomite to avoid $\mathrm{pH}$-induced plant micronutrient deficiency. However, the effects of micronutrient amendments on plant growth in nonlimed pine bark substrates seem to be taxa-specific when assessing results in this study and others in the literature. When growing containerized crops in a pine bark-based substrate, micronutrient fertilization reduced the growth of Juniperus virginiana L. (Wright and Hinesley, 1991), improved growth in nine deciduous tree species (Wright et al., 1999), and had no effect on growth of Rhododendron L. $\times$ 'Girards Scarlet' (Rose and Wang, 1999) compared with plants grown in substrates not amended with a supplemental micronutrient source. In the current study, the limiting nutrients responsible for reduced growth of crape myrtle grown in FL and the control could not be discerned because foliar tissue samples were not analyzed. However, weekly photographs of each plant indicated that at 70 DAI, plants within the FL treatment were visibly smaller and recently matured leaves displayed interveinal chlorosis and necrosis, indicating deficiency of nutrients with low (e.g., Ca, Mn) or intermediate (e.g., $\mathrm{Fe}, \mathrm{Zn}, \mathrm{Cu}, \mathrm{B}, \mathrm{Mo}$ ) phloem mobility (Marschner, 2012).

The observed increase followed by a decrease in TP and TDP concentrations between 42 and 91 DAI in all substrate treatments is similar to that described by Du. et al. (2006), who assessed P release from two polyurethane-coated CRFs in silica sand. The relatively high initial pore-water TDP concentrations at 14 DAI (i.e., $9.5 \pm$ $0.72 \mathrm{mg} \cdot \mathrm{L}^{-1} \mathrm{P}$ ) in the $\mathrm{F}$ and $\mathrm{FL}$ treatments can be primarily attributed to indigenous $\mathrm{P}$ in the pine bark. The total dissolved $\mathrm{P}$ concentration in saturated media extracts of nonamended bark was $7.67 \pm 0.46 \mathrm{mg} \cdot \mathrm{L}^{-1}$, which is equivalent to $\approx 13.7 \mathrm{mg} \cdot \mathrm{L}^{-1}$ TDP when extracted via the pour-through method according to the calibration equation reported by Cavins et al. (2004). These observed indigenous TDP concentrations in pine bark are in line with the range of 6.9 to $9.0 \mathrm{mg} \cdot \mathrm{L}^{-1} \mathrm{P}$ reported by 
Ogden et al. (1987), who reviewed chemical properties of pine bark substrates. Damaged CRF granules have been shown to release an immediate supply of soluble P (Huett and Morris, 1999); however, this was not likely the case in the current study because damaged CRF granules were avoided when weighing CRF for each plant. In addition, extra caution was taken when incorporating the CRF in the pine bark to avoid marring the polymer coating.

\section{Conclusion}

Amending pine bark with a combination of $0.89 \mathrm{~kg} \cdot \mathrm{m}^{-3}$ micronutrients and 2.97 $\mathrm{kg} \cdot \mathrm{m}^{-3}$ dolomite reduced water-extractable OP, TDP, and TP concentrations by $56 \%$ to $58 \%$ without negatively impacting containerized crape myrtle growth or $\mathrm{P}$ uptake. Orthophosphate, the bioavailable form of $\mathrm{P}$, contributed $75 \%$ to $89 \%$ of TP. We deduced that amending pine bark with dolomite and micronutrients reduces $\mathrm{P}$ leaching in open-air nursery production because pour-through extract is comparable to solution leaching from nursery containers from irrigation. Therefore, amending pine bark-based substrates with dolomite and micronutrients may be a best management practice for reducing $\mathrm{P}$ in nursery runoff when crop growth is improved or unchanged by their addition. Further consideration should be given to the abundance of P-reactive elements (e.g., $\mathrm{Mn}, \mathrm{Fe}, \mathrm{Ca}$ ) in routinely applied irrigation water that could further affect $\mathrm{P}$ chemistry and subsequent plant availability. For example, the consistent presence of supersaturated $\mathrm{MnHPO}_{4}$ solid phases in substrate pore-water suggests that $\mathrm{Mn}$ in irrigation water could limit P availability, especially in limed substrate.

\section{Literature Cited}

Altland, J.E. and K.Y. Jeong. 2016. Dolomitic lime amendment affects pine bark substrate $\mathrm{pH}$, nutrient availability, and plant growth: A review. HortTechnology 26:565-573.

Argo, W.R. and J.A. Biernbaum. 1996a. The effect of lime, irrigation-water source, and watersoluble fertilizer on root-zone $\mathrm{pH}$, electrical conductivity, and macronutrient management of container root media with impatiens. J. Amer. Soc. Hort. Sci. 121:442-452.

Argo, W.R. and J.A. Biernbaum. 1996b. Availability and persistence of macronutrients from lime and preplant nutrient charge fertilizers in peatbased root media. J. Amer. Soc. Hort. Sci. $121: 453-460$

Bilderback, T., C. Boyer, M. Chappell, G. Fain, D. Fare, C. Gilliam, B.E. Jackson, J. Lea-Cox, A.V. LeBude, A. Niemiera, J. Owen, J. Ruter, K. Tilt, S. Warren, S. White, T. Whitwell, R. Wright, and T. Yeager. 2013a. Best management practices: Guide for producing nursery crops. 3rd ed. Southern Nursery Association, Acworth, GA.

Bilderback, T.E., E.D. Riley, B.E. Jackson, H.T. Kraus, W.C. Fonteno, J.S. Owen, Jr., J.E. Altland, and G.B. Fain. 2013b. Strategies for developing sustainable substrates in nursery crop production. Acta Hort. 1013:43-56.

Boesch, D.F., R.B. Brinsfield, and R.E. Magnien. 2001. Chesapeake Bay eutrophication: Scien- tific understanding, ecosystem restoration, and challenges for agriculture. J. Environ. Qual. 30:303-320.

Broschat, T. 1995. Nitrate, phosphate, and potassium leaching from container-grown plants fertilized by several methods. HortScience 30:74-77.

Carpenter, S.R., N.F. Caraco, D.L. Correll, R.W. Howarth, A.N. Sharpley, and V.H. Smith. 1998. Nonpoint pollution of surface waters with phosphorus and nitrogen. Ecol. Appl. 8:559-568.

Cavins, T.J., B.E. Whipker, and W.C. Fonteno. 2004. Establishment of calibration curves for comparing pour-through and saturated media extract nutrient values. HortScience 39:16351639.

Correll, D.L. 1998. The role of phosphorous in eutrophication of receiving waters: A review. J. Environ. Qual. 27:261-266.

Dennis, J.H., R.G. Lopez, B.K. Behe, C.R. Hall, C. Yue, and B.L. Campbell. 2010. Sustainable production practices adopted by greenhouse and nursery plant growers. HortScience 45:1232-1237.

Diara, C., L. Incrocci, G. Incrocci, G. Carmassi, A. Pardossi, P. Marzialetti, P. Cozzi, F. Fibbi, and R. Clemens. 2014. Reduction of nutrient runoff by the use of coated slow-release fertilizers on two container-grown nursery crops. Acta Hort. 1034:85-92.

Du, C., J. Zhou, and A. Shaviv. 2006. Release characteristics of nutrients from polymercoated compound controlled release fertilizers. J. Polym. Environ. 14:223-230.

Fain, G.B., C.H. Gilliam, K.M. Tilt, J.W. Olive, and B. Wallace. 2000. Survey of best management practices in container production nurseries. J. Environ. Hort. 18:142-144.

Fonteno, W.C., C.T. Hardin, and J.P. Brewster. 1995. Procedures for determining physical properties of horticultural substrates using the NCSU Porometer. Horticultural Substrates Laboratory. NC State University, Raleigh, NC. $<$ https://projects.ncsu.edu/project/hortsublab/ pdf/porometer_manual.pdf $>$.

Gustafsson, J.P. 2013. Visual MINTEQ ver. 3.1. $<$ https://vminteq.lwr.kth.se/>.

Handreck, K.A. 1996. Comparison of phosphatephosphorus and total phosphorus in DTPA extracts for assessing plant-available phosphorus in soilless potting media. Commun. Soil Sci. Plant Anal. 27(9-10):2125-2135.

Havis, J.R. and J.H. Baker. 1985. Influence of liming rate and phosphorus leaching from a peat-sand medium. J. Environ. Hort. 3:74-76.

Haynes, J.R. 1982. Leaching losses of nutrients and yield and nutrient uptake by container-grown begonia as affected by lime and fertilizer applications to a peat medium. J. Sci. Food Agr. 33:407-413.

Huett, D.O. and S.C. Morris. 1999. Fertiliser use efficiency by containerised nursery plants 3 . Effect of heavy leaching and damaged fertilizer prills on plant growth, nutrient uptake, and nutrient loss. Aust. J. Agr. Res. 50:217-222.

Islam, K.M.S., D.G. Edwards, and C.J. Asher 1980. pH optima for crop growth. Plant Soil 54:339-357.

Johnson, N.L. 1949. Systems of frequency curves generated by methods of translation. Biometrika 36:149-176.

Karaca, S., A. Gürses, M. Edjer, and M. Açıkyıldız. 2004. Kinetic modeling of liquid-phase adsorption and phosphate on dolomite. J. Colloid Interface Sci. 277:257-263.

Karaca, S., A. Gürses, M. Edjer, and M. Açıyııldız. 2006. Adsorptive removal of phosphate from aqueous solutions using raw and calcinated dolomite. J. Hazard. Mater. B128:273-279.

Khan, M.N. and F. Mohammad. 2014. Eutrophication: Challenges and solutions. In A.A. Ansari and S.S. Gill (eds.). Eutrophication: Causes, consequences and control. Volume 2. Springer, Dordrecht, Heidelberg, London, New York.

Krishnan, K.A. and A. Haridas. 2008. Removal of phosphate from aqueous solutions and sewage using natural and surface modified coir pith. J. Hazard. Mater. 152:527-535.

Lea-Cox, J.D. and A.G. Ristvey. 2003. Why are nutrient uptake efficiencies so low in ornamental plant production. Proc. South. Nurs. Assoc. Res. Conf. 48:116-122.

Lu, W., J.L. Sibley, C.H. Gilliam, J.S. Bannon, and Y. Zhang. 2006. Estimation of U.S. bark generation and implications for horticultural industries. J. Environ. Hort. 24:29-34.

Mack, R., J.S. Owen, A.X. Niemiera, and J. Latimer. 2017. Virginia nursery and greenhouse grower survey of best management practices. HortTechnology 27:386-392.

Mangwandi, C., A.B. Albadarin, Y. Glocheux, and G.M. Walker. 2014. Removal of orthophosphate form aqueous solution by adsorption onto dolomite. J. Environ. Chem. Eng. 2:11231130

Marconi, D.J. and P.V. Nelson. 1984. Leaching of applied phosphorous in container media. Scientia Hort. 22:275-285.

Marschner, H. 2012. Mineral nutrition of higher plants. 3rd ed. Academic Press, San Diego, CA.

McGinnis, M.S., S.L. Warren, and T.E. Bilderback. 2009. Replacing conventional nursery crop nutrient inputs with vermicompost for container production of Hibiscus moscheutos L. 'Luna Blush'. HortScience 44:1690-1703.

Michalak, A.M., E.J. Anderson, D. Beletsky, S. Boland, N.S. Bosch, T.B. Bridgeman, J.D. Chaffin, K. Cho, R. Confesor, I. Daloglu, J.V. DePinto, M.A. Evans, G.L. Fahnenstiel, L. He, J.C. Ho, L. Jenkins, T.H. Johengen, K.C. Kuo, E. LaPorte, X. Liu, M.R. McWilliams, M.R Moore, D.J. Posselt, R.P. Richards, D. Scavia, A.L. Steiner, E. Verhamme, D.M. Wright, and M.A. Zagorski. 2015. Record-setting algal bloom in Lake Erie caused by agricultural and meteorological trends consistent with expected future conditions. Proc. Natl. Acad. Sci. USA 110:6448-6452.

Million, J., T. Yeager, and J. Albano. 2007a. Effects of container spacing practice and fertilizer placement on runoff from overheadirrigated sweet viburnum. J. Environ. Hort. 25:61-72.

Million, J., T. Yeager, and J. Albano. 2007b. Consequences of excessive overhead irrigation on runoff during container production of sweet viburnum. J. Environ. Hort. 25:117-125.

Murphy, J. and J.P. Riley. 1962. A modified single solution method for the determination of phosphate in natural waters. Anal. Chim. Acta 27:31-36.

Ogden, R.J., F.A. Pokorny, H.A. Mills, and M.G. Dunavent. 1987. Elemental status of pine barkbased potting media. Hort. Rev. 9:103-131.

Ogutu, R.A. and K.A. Williams. 2009. Phosphate sorption of calcined materials used as components of soilless root media characterized in laboratory studies. HortScience 44:431-437.

Okubo, Y., T. Inoue, and K. Yokota. 2012. Estimating bioavailability of soil particulate phosphorus to Microcystis aeruginosa. J. Appl. Phycol. 24:1503-1507.

Owen, J.S., Jr., S.L. Warren, T.E. Bilderback, and J.P. Albano. 2007. Industrial mineral aggregate amendment affects physical and chemical 
properties of pine bark substrates. HortScience 42:1287-1294.

Owen, J.S., S.L. Warren, T.E. Bilderback, and J.P. Albano. 2008. Phosphorus rate, leaching fraction, and substrate influence on influent quantity, effluent nutrient content, and response of a containerized woody ornamental crop. HortScience 43:906-912.

Paradelo, R., M. Conde-Cid, M. Arias-Estévez, J.C. Nóvoa-Muñoz, E. Álvarez-Rodríguez, M.J. Fernández-Sanjurjo, and A. Núñez-Delgado. 2017. Removal of anionic pollutants by pine bark influenced by the mechanism of retention. Chemosphere 167:139-145.

Peters, J.B., S. Combs, B. Hoskins, J. Jarman, J. Kovar, M. Watson, A. Wolf, and N. Wolf. 2003. Recommended methods of manure analysis. UWEX Pub. A3769, Univ. of WisconsinExtension, Madison, WI.

Ristvey, A.G., J.D. Lea-Cox, and D.S. Ross. 2004. Nutrient uptake, partitioning and leaching losses from container-nursery production systems. Acta Hort. 630:321-328.

Ristvey, A.G., J.D. Lea-Cox, and D.S. Ross. 2007. Nitrogen and phosphorus uptake efficiency and partitioning of container-grown azalea during spring growth. J. Amer. Soc. Hort. Sci. 132:563-572.

Rose, M.A. and H. Wang. 1999. Comparison of micronutrient sources for container rhododendron. HortTechnology 9:220-224.

Ruter, J.M. 2004. Rate of calcined clay incorporation influences phosphorus retention in a pine bark substrate. Proc. South. Nurs. Assoc. Res. Conf. 49:23-24.

Schindler, D.W., R.E. Hecky, D.L. Findlay, M.P. Stainton, B.R. Parker, M.J. Paterson, K.G. Beaty, M. Lyng, and S.E.M. Kasian. 2008. Eutrophication of lakes cannot be controlled by reducing nitrogen input: Results of a 37-year whole-ecosystem experiment. Proc. Natl. Acad. Sci. USA 105:11254-11258.

Shreckhise, J.H., J.S. Owen, Jr., M.J. Eick, A.X. Niemiera, J.E. Altland, and S.A. White. 2019.
Dolomite and micronutrient fertilizer affect phosphorus fate in pine bark substrate used for containerized nursery crop production. Soil Sci. Soc. J. doi: 10.2136/sssaj2018.12.0493.

Tanaka, A., K. Fujita, and K. Kikuchi. 1974. Nutrio-physiological studies on the tomato plant. Soil Sci. Plant Nutr. 20:57-68.

Timmer, V.R. 1991. Interpretation of seedling analysis and visual symptoms, p. 113-134. In: R. van den Driessche (ed.). Mineral nutrition of conifer seedlings. CRC Press, Boca Raton, FL.

Tyler, H.H., S.L. Warren, and T.E. Bilderback. 1996a. Cyclic irrigation increases irrigation application efficiency and decreases ammonium losses. J. Environ. Hort. 14:194-198.

Tyler, H.H., S.L. Warren, and T.E. Bilderback. 1996b. Reduced leaching fractions improve irrigation use efficiency and nutrient efficacy. J. Environ. Hort. 14:199-204.

Uusitalo, R., E. Turtola, M. Puustinen, M. PaasonenKivekäs, and J. Uusi-Kämppä. 2003. Contribution of particulate phosphorus to runoff phosphorus bioavailability. J. Environ. Qual. 32:20072016.

Van Moorleghem, C., L. Six, F. Degryse, E. Smolders, and R. Merckx. 2011. Effect of organic $\mathrm{P}$ forms and $\mathrm{P}$ present in inorganic colloids on the determination of dissolved $\mathrm{P}$ in environmental samples by the diffusive gradient in thin films technique, ion chromatography, and colorimetry. Anal. Chem. 83:5317-5323.

Warncke, D.D. 1986. Analyzing greenhouse growth media by the saturation extraction method. HortScience 21:223-225.

Warren, S.L., T.E. Bilderback, and H.H. Kraus. 2001. Method of fertilizer application affects nutrient losses of controlled-release fertilizer. Acta Hort. 548:349-355.

Warren, S.L., T.E. Bilderback, and H.H. Tyler. 1995. Efficacy of three nitrogen and phosphorus sources in container-grown azalea production. J. Environ. Hort. 13:147-151.
Wolfinger, R. 1993. Covariance structure selection in general mixed models. Commun. Stat. 22:10791106.

Wright, A.N., A.X. Niemiera, J.R. Harris, and R.D. Wright. 1999. Preplant lime and micronutrient amendments to pine bark affect growth of seedlings of nine container-grown tree species. HortScience 34:669-673.

Wright, R.D. 1986. The pour-through nutrient extraction procedure. HortScience 21:227229.

Wright, R.D. and L.E. Hinesley. 1991. Growth of containerized Eastern redcedar amended with dolomitic limestone and micronutrients. HortScience 26:143-145.

Xu, G., I. Levkovitch, S. Soriano, R. Wallach, and A. Silber. 2004. Integrated effect of irrigation frequency and phosphorus level on lettuce: $\mathrm{P}$ uptake, root growth and yield. Plant Soil 263:297-309.

$\mathrm{Xu}, \mathrm{N} ., \mathrm{H}$. Yin, Z. Chen, S. Liu, M. Chen, and J. Zhang. 2014. Mechanisms of phosphate retention by calcite: Effects of magnesium and $\mathrm{pH}$. J. Soils Sediments 14:495-503.

Yeager, T.H. and R.D. Wright. 1982. Pine barkphosphorus relationships. Commun. Soil Sci. Plant Anal. 13:57-66.

Yuan, X., W. Xia, J. An, W. Yang, and J. Yin. 2014. Removal of phosphate anions from aqueous solutions using dolomite as adsorbent. Adv. Mater. Res. 864-867:1454-1457.

Yuan, X., X. Wentag, J. An, J. Yin, X. Zhou, and W. Yang. 2015. Kinetic and thermodynamic studies on the phosphate adsorption removal by dolomite mineral. J. Chem. 2015:1-8, doi: 10.1155/2015/853105.

Zhang, R., T. Leiviska, S. Taskila, and J. Tanskanen. 2018. Iron-loaded sphagnum moss extract residue for phosphate removal. J. Environ. Manage. 218:271-279. 